POLY-D-16-00134_R1_19feb16

\title{
Zinc and Cadmium Halide Compounds with the tridentate ligand 2-(methylsulfanyl)-N-(pyridin-2-ylmethylidene)aniline showing yellow luminescence.
}

\author{
Xue Liu, ${ }^{a}$ Adriana González-Castro, ${ }^{a}$ Ilpo Mutikainen, ${ }^{b}$ Andrej Pevec, ${ }^{\mathrm{c}}$ Simon J. Teat, ${ }^{\mathrm{d}}$ \\ Patrick Gamez, ${ }^{\mathrm{a}, \mathrm{e}}$ Jose Sanchez Costa, ${ }^{\mathrm{a}, \mathrm{f}}$ Elisabeth Bouwman, ${ }^{\mathrm{a},}{ }^{\mathrm{N}}$ Jan Reedijk ${ }^{\mathrm{a}}$
}

a Leiden Institute of Chemistry, Gorlaeus Laboratories, Leiden University, P.O. Box 9502, 2300 RA

Leiden, The Netherlands; E-mail: bouwman@chem.leidenuniv.nl. Tel: +31(0)71 5274450.

b Department of Chemistry, University of Helsinki, P.O. Box 55 (A.I. Virtasenaukio 1), FI-00014,

Finland

c Faculty of Chemistry and Chemical Technology, University of Ljubljana, Večna pot 113, Ljubljana, Slovenia

d Advanced Light Source, Lawrence Berkeley National Laboratory, 1 Cyclotron Rd, Berkeley, CA, 94720, USA

e: Current address: Catalan Institution for Research and Advanced Studies (ICREA), Passeig Lluís

Companys 23, 08010 Barcelona, Spain

f: Current address: IMDEA-Nanoscience c/Faraday 9, Campus Cantoblanco, 28049 Madrid, Spain

\begin{abstract}
Five mononuclear complexes, i.e. $\mathrm{ZnLCl}_{2}$ (1), $\left[\mathrm{ZnLBr}_{2}\right]\left(\mathrm{CH}_{3} \mathrm{CN}\right)$ (2), $\mathrm{ZnLBr}_{2}$ (3), $\mathrm{CdLCl}_{2}$ (4), and $\mathrm{CdLBr}_{2}(5)$, with $\mathrm{L}=2$-(methylsulfanyl)-N-(pyridin-2-ylmethylidene)aniline, have been synthesized and characterized. For $\left[\mathrm{ZnLBr}_{2}\right]\left(\mathrm{CH}_{3} \mathrm{CN}\right)$ only a few crystals were obtained from the main batch of $\mathrm{ZnLBr}_{2}$. Their crystal structures and solid-state luminescence properties both at room temperature and $77 \mathrm{~K}$ have been investigated. All compounds contain 5-coordinated $\mathrm{Zn}$ (II) or $\mathrm{Cd}(\mathrm{II})$ ions in a square-pyramidal geometry, distorted towards trigonal bipyramidal. The phase purity of all compounds has been evaluated by Powder XRD and IR. All five compounds show photoluminescent properties both at room temperature and $77 \mathrm{~K}$. In the solid state, the compounds exhibit yellow luminescence with the maximum of emission at around $540 \mathrm{~nm}$. By cooling down to $77 \mathrm{~K}$, the shape and position of the emission spectra of all these compounds remains more or less constant.
\end{abstract}




\section{Keywords:}

Zinc(II); Cadmium(II); Schiff base; Chloride; Bromide; Luminescence

\section{Introduction}

Luminescent materials based on transition metals and lanthanoids have found wide applications in lighting [1-3], luminescence sensing [4-6] and optical devices [7]. Among them, $\mathrm{d}^{10}$ metal complexes comprising zinc(II) and cadmium(II) with a variety of ligands have drawn extensive attention in the past decades due to their attractive luminescence properties [8-10]. Schiff bases have been widely employed in coordination chemistry due to their easy accessibility and structural varieties [11]. Transition metal Schiff-base complexes show great importance in catalysis [12], photochemistry [13], biochemistry [14] and materials science [15].

Selected zinc(II) and cadmium(II) Schiff-base complexes with excellent luminescence properties have been reported in the literature[16, 17]. In this work, we have synthesized a series of mononuclear zinc(II) and cadmium(II) coordination compounds using the tridentate NNS-donor Schiff-base ligand 2-(methylsulfanyl)-N-(pyridin-2-ylmethylidene)aniline (abbreviated as L). The characterization and structure determination of the compounds have been performed through NMR, IR, elemental analysis, X-ray crystallography and Powder XRD. The photophysical properties have been studied by solid-state absorption spectra and further by solidstate excitation and emission spectra. During the writing phase of the paper it was found that the zinc bromide compound was studied in 1972, but only its crystal structure was reported [18]. This structure appears to be isomorphous with our compound, $\mathrm{ZnLBr}_{2}$, but determined at room $\mathrm{T}$ and reported with a higher $\mathrm{R}$ value.

\section{Experimental part}

\subsection{Materials and general methods}

2-(Methylthio)aniline and pyridine-2-carboxaldehyde were purchased from SigmaAldrich. Pyridine-2-carboxaldehyde was distilled before use; the other chemicals and solvents were used without further purification. ${ }^{1} \mathrm{H}$ and ${ }^{13} \mathrm{C}$ NMR spectra were recorded on a Bruker DPX300 spectrometer. Elemental analysis for C, H, N was performed at the Microanalytical laboratory Kolbe in Germany. FT-IR spectra were recorded on a Perkin-Elmer Paragon 1000 FTIR spectrophotometer equipped with a Golden Gate ATR device. X-ray powder diffraction patterns were obtained on a Philips PW 1050 diffractometer using $\mathrm{Cu} \operatorname{Ka}$ radiation $(\lambda=1.542 \AA)$. 
The room-temperature excitation and emission spectra were measured on a Shimadzu RF5301PC spectrofluoriphotometer. Solid-state absorption spectra were recorded with the Avantes absorbance setup, using the Avantes AvaSpec-2048UA CCD spectrometer as detector, and the AvaLight-DH-S Deuterium-Halogen light source. The low-temperature emission spectra (77 K) were measured using a homemade sample holder with an irradiance calibrated CCD spectrometer (Avantes AvaSpec-2048UA) as a detector. A $1000 \mathrm{~W}$ xenon lamp (LOT) and a Spex monochromator were used as the excitation source. Photoluminescence quantum yields were measured using the absolute method.[19] An integrating sphere (Avantes AvaSphere 30REFL) and an CCD spectrometer (Avantes AvaSpec-2048UA) was used.

\subsection{Ligand synthesis}

The ligand 2-(methylsulfanyl)-N-(pyridin-2-ylmethylidene)aniline (L) was synthesized following a literature procedure [20]. A solution of 2-(methylthio)aniline (0.64 g, $4.6 \mathrm{mmol})$ and fresh distilled pyridine-2-carboxaldehyde $(0.50 \mathrm{~g}, 4.6 \mathrm{mmol})$ in toluene $(50 \mathrm{~mL})$ was refluxed for $24 \mathrm{~h}$. The reaction mixture was then filtered and the solvent was evaporated under reduced pressure. The crude product was recrystallized from toluene/hexane. Yellow crystals of pure ligand were obtained. Yield: $0.83 \mathrm{~g}(75 \%) .{ }^{1} \mathrm{H}$ NMR $\left(300 \mathrm{MHz}, \mathrm{CDCl}_{3}\right): \delta=8.67(\mathrm{~d}, 1 \mathrm{H}), 8.57$ (s, $1 \mathrm{H}), 8.33(\mathrm{~d}, 1 \mathrm{H}), 7.80(\mathrm{t}, 1 \mathrm{H}), 7.36(\mathrm{t}, 1 \mathrm{H}), 7.27(\mathrm{~m}, 3 \mathrm{H}), 7.06(\mathrm{~d}, 1 \mathrm{H}), 2.47(\mathrm{~s}, 3 \mathrm{H}) \mathrm{ppm} .{ }^{13} \mathrm{C}$ NMR (300 MHz, $\left.\mathrm{CDCl}_{3}\right): \delta=160.3,154.7,149.6,147.9,136.7,134.8,127.33,125.3,125.2$, 124.6, 122.0, 117.5, 14.86 ppm. IR (v): 1620 (m), 1469 (s), 1433 (s), 1346 (w), 1266 (w), 1194 (w), $1068(\mathrm{w}), 1040(\mathrm{w}), 992$ (m), 879 (s), 778 (vs), 749 (vs), 739 (vs), 726 (vs), 691 (s), 648 (m), 613 (s), 549 (s), 481 (vs) $\mathrm{cm}^{-1}$.

\subsection{General procedure for synthesis of the compounds $\mathrm{ZnLCl}_{2}(1), \mathrm{ZnLBr}_{2}$ (2) + (3), $\mathrm{CdLCl}_{2}$} (4), and $\mathrm{CdLBr}_{2}$ (5).

The ligand $\mathrm{L}(0.22 \mathrm{~g}, 1 \mathrm{mmol})$ was dissolved in $10 \mathrm{~mL} \mathrm{MeOH}$. To this solution, the metal salt ( $1 \mathrm{mmol} ; \mathrm{ZnCl}_{2}, \mathrm{ZnBr}_{2}, \mathrm{CdCl}_{2}$ and $\mathrm{CdBr}_{2}$, respectively) in $\mathrm{MeOH}(10 \mathrm{~mL}$ ) was added dropwise; the mixture was then stirred at $80{ }^{\circ} \mathrm{C}$ for $2 \mathrm{~h}$. The precipitate was filtered and washed with hot $\mathrm{MeOH}$ three times, then dried in air. The yellow compounds were finally recrystallized from acetonitrile. $\mathrm{ZnLCl}_{2}$ (1), yield: $0.25 \mathrm{~g}(70 \%)$; $\mathrm{ZnLBr}_{2}(\mathbf{2}+\mathbf{3})$, yield: $0.25 \mathrm{~g}$ (54\%); $\mathrm{CdLCl}_{2}(\mathbf{4})$,

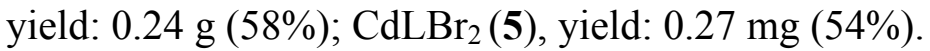

Basic spectroscopic data for each compound: 
$\mathrm{ZnLCl}_{2}$ (1). ${ }^{1} \mathrm{H}$ NMR (300 MHz, DMSO): $\delta=8.76(\mathrm{~d}, J=4.7 \mathrm{~Hz}, 1 \mathrm{H}), 8.57(\mathrm{~s}, 1 \mathrm{H}), 8.18$ (d, $J=7.9 \mathrm{~Hz}, 1 \mathrm{H}), 8.02(\mathrm{t}, J=7.7 \mathrm{~Hz}, 1 \mathrm{H}), 7.59(\mathrm{~m}, 1 \mathrm{H}), 7.30(\mathrm{~m}, 2 \mathrm{H}), 7.24(\mathrm{~m}, 2 \mathrm{H}), 2.44$ (s, 3H) ppm. ${ }^{13} \mathrm{C}$ NMR (300 MHz, DMSO): $\delta=160.7,150.3,137.8,128.0,126.5,125.6,124.9,122.1$, 118.1, 14.3 ppm. Elemental analysis found (calc) for $\mathrm{C}_{13} \mathrm{H}_{12} \mathrm{Cl}_{2} \mathrm{~N}_{2} \mathrm{SZn}$ : C, 42.92 (42.83); H, 3.31 (3.32); N, 7.83 (7.68); S, 8.66 (8.79). IR (v): 1627 (w), 1596 (s), 1563 (w), 1479 (w), 1441 (s), 1368 (m), 1298 (s), 1235 (m), 1203 (m), 1100 (m), 1044 (m), 1020 (s), 978 (s), 952 (m), 911 (m), 778 (vs), 744 (vs), 642 (s), 565 (s), 495 (s), 469 (s) $\mathrm{cm}^{-1}$.

$\mathrm{ZnLBr}_{2}(\mathbf{2 + 3}) .{ }^{1} \mathrm{H}$ NMR (300 MHz, DMSO): $\delta=8.76$ (d, $\left.J=4.8 \mathrm{~Hz}, 1 \mathrm{H}\right), 8.56(\mathrm{~s}, 1 \mathrm{H}), 8.19$ $(\mathrm{d}, J=8.5 \mathrm{~Hz}, 1 \mathrm{H}), 8.02(\mathrm{t}, J=7.7 \mathrm{~Hz}, 1 \mathrm{H}), 7.59(\mathrm{~m}, 1 \mathrm{H}), 7.31(\mathrm{~m}, 2 \mathrm{H}), 7.24(\mathrm{~m}, 2 \mathrm{H}), 2.45(\mathrm{~s}, 3 \mathrm{H})$ ppm. ${ }^{13} \mathrm{C}$ NMR (300 MHz, DMSO): $\delta=160.7,150.3$, 137.8, 127.9, 126.4, 125.6, 124.8, 122.0, 118.1, 14.3 ppm. Elemental analysis found (calc) for $\mathrm{C}_{13} \mathrm{H}_{12} \mathrm{Br}_{2} \mathrm{~N}_{2} \mathrm{SZn}$ : C, 34.91 (34.43); H, 2.79 (2.67); N, 6.30 (6.18); S, 6.84 (7.07). IR (v): 1618 (w), 1588 (s), 1559 (w), 1474 (m), 1428 (s), 1369 (s), 1301 (s), 1238 (m), 1198 (m), 1150 (m), 1094 (m), 1044 (m), 1016 (s), 980 (s), 912 (m), 796 (vs), 767 (s), 761 (s), 744 (vs), 722 (s), 640 (s), 575 (s), 497 (s), 465 (w) cm cm $^{-1}$ After recrystallization from $\mathrm{MeCN}$ the sample showed visually distinguishable two kinds of crystals (in an approximate ratio of 1:5); two different crystals (i.e. 2 and 3) were used for single-crystal XRD studies.

$\mathrm{CdLCl}_{2}$ (4). ${ }^{1} \mathrm{H}$ NMR (300 MHz, DMSO): $\delta=8.76$ (d, $\left.J=3.9 \mathrm{~Hz}, 1 \mathrm{H}\right), 8.60$ (s, 1H), 8.18 (d, $J=7.8 \mathrm{~Hz}, 1 \mathrm{H}), 8.04(\mathrm{t}, J=7.7 \mathrm{~Hz}, 1 \mathrm{H}), 7.68(\mathrm{~m}, 1 \mathrm{H}), 7.32(\mathrm{~m}, 2 \mathrm{H}), 7.25(\mathrm{~m}, 2 \mathrm{H}), 2.44(\mathrm{~s}, 3 \mathrm{H})$ ppm. ${ }^{13} \mathrm{C}$ NMR (300 MHz, DMSO): $\delta=160.8,150.3$, 138.0, 128.0, 126.6, 125.7, 125.1, 122.7, 118.4, 14.5 ppm. Elemental analysis found (calc) for $\mathrm{C}_{13} \mathrm{H}_{12} \mathrm{Cl}_{2} \mathrm{~N}_{2} \mathrm{SCd}$ : C, 38.40 (37.93); H, 2.91 (2.94); N, 6.94 (6.81); S, 7.26 (7.79). IR (v): 1624 (w), 1590 (s), 1563 (w), 1479 (w), 1438 (s), 1372 (m), 1304 (s), 1236 (m), 1199 (m), 1101 (m), 1014 (s), 979 (s), 965 (m), 910 (m), 776 (vs), 761 (vs), 741 (vs), 637 (s), 572 (s), 498 (s), 465 (s) $\mathrm{cm}^{-1}$.

$\mathrm{CdLBr}_{2}(\mathbf{5}) .{ }^{1} \mathrm{H}$ NMR (300 MHz, DMSO): $\delta=8.76$ (d, J=4.7 Hz, 1H), 8.59 (s, 1H), 8.19 (d, $J=7.9 \mathrm{~Hz}, 1 \mathrm{H}), 8.05(\mathrm{t}, J=7.6 \mathrm{~Hz}, 1 \mathrm{H}), 7.60(\mathrm{~m}, 1 \mathrm{H}), 7.32(\mathrm{~m}, 2 \mathrm{H}), 7.26(\mathrm{~m}, 2 \mathrm{H}), 2.45(\mathrm{~s}, 3 \mathrm{H})$ ppm. ${ }^{13} \mathrm{C}$ NMR (300 MHz, DMSO): $\delta=160.8,150.3,138.0,128.0,126.7,125.7,125.1,122.7$, 118.4, 14.5 ppm. Elemental analysis found (calc) for $\mathrm{C}_{13} \mathrm{H}_{12} \mathrm{Br}_{2} \mathrm{~N}_{2} \mathrm{SCd}$ : C, 31.56 (31.20); H, 2.26 (2.42); N, 5.68 (5.60); S, 6.18 (6.41). IR (v): 1628 (w), 1590 (s), 1567 (w), 1475 (m), 1435 (m), 1373 (s), 1304 (m), 1232 (m), 1198 (m), 1097 (m), 1044 (m), 1011 (m), 984 (s), 903 (s), 780 (vs), 758 (vs), 743 (s), 637 (s), 571 (s), 492 (s), 460 (m) $\mathrm{cm}^{-1}$. 


\section{4: Single Crystal Structure Determinations}

A single crystal of compound $\mathbf{1}$ was mounted at the diffractometer and measured both at room temperature $(293 \mathrm{~K})$ and at $173 \mathrm{~K}$ by using a Nonius Kappa CCD area detector diffractometer. A graphite monochromated $\mathrm{MoK} \alpha$ radiation source $(\lambda=0.71073 \AA)$ was employed. Standard programs like SIR-92 [21], SHELXS-97 and SHELXL-97 [22] were used for data structure solution and structure refinement. The structure was solved by direct methods using and refined with a full-matrix least-squares procedure based on $F^{2}$ using. All of the nonhydrogen atoms were refined anisotropically. All other $\mathrm{C}-\mathrm{H}$ hydrogen atoms (except C7-H7A) were included in the model at geometrically calculated positions and refined using a riding model. The hydrogen atom bonded to C7 was visible in the last stages of refinement and was refined freely (distance C7-H7A = 0.93(2) Å). See Table 1 for more details.

Crystals of 2, 3 and 4 were selected for the X-ray measurements and mounted to nylon loop using the oil-drop method [23] and data were collected using Bruker Kappa APEXII diffractometer (Mo-K $\alpha$ radiation, $\lambda=0.71073 \AA$ ) at $123 \mathrm{~K}$. A crystal of 5 was mounted on a MitGen loop in oil and data collected on Bruker APEX2 CCD diffractometer at beamline 11.3.1 of the Advanced Light Source (Synchrotron radiation, $\lambda=0.7749 \AA$ ) at $100 \mathrm{~K}$. A total of 658 frames for $\mathrm{CdLCl}_{2}, 1159$ frames for $\left[\mathrm{ZnLBr}_{2}\right]\left(\mathrm{CH}_{3} \mathrm{CN}\right), 718$ frames for $\mathrm{ZnLBr}_{2}$ and 2880 frames for $\mathrm{CdLBr}_{2}$ were collected. The frames were integrated with the Bruker SAINT software package [24] using a narrow-frame algorithm and their intensities were corrected for Lorentz and polarization effects. An absorption correction was applied using the Multi-Scan method (SADABS) [24]. The programs SHELXS2014 [22], SHELXL2014 [25] were used for structure solution and structure refinement. The non-hydrogen atoms were refined anisotropically. The $\mathrm{H}$ atoms were situated at calculated positions and refined isotropically riding with the heavy atom connected. More details are in Tables 1 and 2. 
Table 1. Crystallographic data collection and refinement of (1), (2) and (3).

\begin{tabular}{|c|c|c|c|c|}
\hline Compound & (1)Low T: $\mathrm{ZnLCl}_{2}$ & (1) Room T: $\mathrm{ZnLCl}_{2}$ & (2) $\mathrm{ZnLBr}_{2}\left(\mathrm{CH}_{3} \mathrm{CN}\right)$ & (3) $\mathrm{ZnLBr}_{2}$ \\
\hline $\mathrm{CCDC}$ & 1445927 & 1446902 & 1443691 & 1446921 \\
\hline Chemical formula & $\mathrm{C}_{13} \mathrm{H}_{12} \mathrm{Cl}_{2} \mathrm{~N}_{2} \mathrm{SZn}$ & $\mathrm{C}_{13} \mathrm{H}_{12} \mathrm{Cl}_{2} \mathrm{~N}_{2} \mathrm{SZn}$ & $\mathrm{C}_{15} \mathrm{H}_{15} \mathrm{Br}_{2} \mathrm{~N}_{3} \mathrm{SZn}$ & $\mathrm{C}_{13} \mathrm{H}_{12} \mathrm{Br}_{2} \mathrm{~N}_{2} \mathrm{SZn}$ \\
\hline Formula mass & 364.59 & 364.59 & 494.50 & 453.50 \\
\hline Temperature $(\mathrm{K})$ & $173(2)$ & $293(2)$ & $123(2)$ & $123(2)$ \\
\hline Crystal system & monoclinic & monoclinic & monoclinic & triclinic \\
\hline Space group & $P 21 / \mathrm{c}$ & $P 21 / \mathrm{c}$ & $P 21 / \mathrm{n}$ & $P-1$ \\
\hline $\mathrm{a} / \AA ̊$ & $8.1510(10)$ & $8.2405(2)$ & $8.1053(4)$ & $8.0102(4)$ \\
\hline $\mathrm{b} / \AA \hat{A}$ & $27.268(3)$ & $27.6821(6)$ & $24.6650(12)$ & $9.3086(5)$ \\
\hline $\mathrm{c} / \AA \hat{~}$ & $6.9880(10)$ & $7.09100(10)$ & $9.0573(4)$ & $10.9516(6)$ \\
\hline$\alpha / \circ$ & 90 & 90 & 90 & $76.836(2)$ \\
\hline$\beta / \circ$ & $113.640(10)$ & $114.2888(1)$ & $101.970(10)$ & $72.701(2)$ \\
\hline$\gamma / \circ$ & 90 & 90 & 90 & $76.094(2)$ \\
\hline $\mathrm{V}\left(\AA^{3}\right)$ & $1422.8(3)$ & $1474.38(5)$ & $1771.34(15)$ & $745.97(7)$ \\
\hline $\mathrm{Z}$ & 4 & 4 & 4 & 2 \\
\hline Radiation type & $\mathrm{MoK} \alpha$ & $\operatorname{MoK} \alpha$ & $\operatorname{MoK} \alpha$ & $\operatorname{MoK} \alpha$ \\
\hline Density (calculated $\mathrm{g} / \mathrm{cm}^{-3}$ ) & 1.702 & 1.642 & 1.854 & 2.019 \\
\hline $\begin{array}{l}\text { Absorption coefficient } \\
\qquad\left(\mathrm{mm}^{-1}\right)\end{array}$ & 2.233 & 2.155 & 6.014 & 7.129 \\
\hline $\mathrm{F}(000)$ & 736 & 736 & 968 & 440 \\
\hline Crystal size $\left(\mathrm{mm}^{3}\right)$ & $0.30 \times 0.30 \times 0.15$ & $0.2 \times 0.08 \times 0.08$ & $0.40 \times 0.35 \times 0.35$ & $0.30 \times 0.12 \times 0.12$ \\
\hline Goodness of fit on $\mathrm{F}^{2}$ & 1.110 & 1.049 & 1.151 & 1.109 \\
\hline $\mathrm{R} 1, w \mathrm{w} 2[\mathrm{I}>2 \sigma(\mathrm{I})]$ & $0.0272,0.0562$ & $0.0273,0.0625$ & $0.0200,0.0441$ & $0.0189,0.0440$ \\
\hline R1, wR2 (all data) & $0.0311,0.0576$ & $0.0446,0.0678$ & $0.0237,0.0451$ & $0.0230,0.0452$ \\
\hline
\end{tabular}


Table 2. Crystallographic data collection and refinement of (4) $\mathrm{CdLBr}_{2}(\mathbf{5})$.

\begin{tabular}{|c|c|c|}
\hline Compound & (4) $\mathrm{CdLCl}_{2}$ & (5) $\mathrm{CdLBr}_{2}$ \\
\hline $\mathrm{CCDC}$ & 1443712 & 1445920 \\
\hline Chemical formula & $\mathrm{C}_{13} \mathrm{H}_{12} \mathrm{Cl}_{2} \mathrm{~N}_{2} \mathrm{SCd}$ & $\mathrm{C}_{13} \mathrm{H}_{12} \mathrm{Br}_{2} \mathrm{~N}_{2} \mathrm{SCd}$ \\
\hline Formula mass & 411.61 & 500.53 \\
\hline Temperature $(\mathrm{K})$ & $123(2)$ & $100(2)$ \\
\hline Crystal system & triclinic & triclinic \\
\hline Space group & $P-1$ & $P-1$ \\
\hline $\mathrm{a} / \hat{A}$ & $7.5791(3)$ & $7.6731(4)$ \\
\hline $\mathrm{b} / \hat{A}$ & $8.6549(4)$ & $8.9064(4)$ \\
\hline $\mathrm{c} / \hat{\AA}$ & $11.3533(5)$ & $11.5492(6)$ \\
\hline$\alpha /{ }^{\circ}$ & $84.1060(10)$ & $84.129(2)$ \\
\hline$\beta / \circ$ & $81.7830(10)$ & $80.050(2)$ \\
\hline$\gamma /{ }^{\prime}$ & $82.8210(10)$ & $81.189(2)$ \\
\hline $\mathrm{V}\left(\hat{\AA}^{3}\right)$ & $728.58(5)$ & $765.89(7)$ \\
\hline $\mathrm{Z}$ & 2 & 2 \\
\hline Radiation type & $\operatorname{MoK} \alpha$ & Synchrotron; $0.77490 \dot{A}$ \\
\hline Density (calculated $\mathrm{g} / \mathrm{cm}^{-3}$ ) & 1.876 & 2.170 \\
\hline Absorption coefficient $\left(\mathrm{mm}^{-1}\right)$ & 1.994 & 8.364 \\
\hline $\mathrm{F}(000)$ & 404 & 476 \\
\hline Crystal size $\left(\mathrm{mm}^{3}\right)$ & $0.30 \times 0.28 \times 0.08$ & $0.06 \times 0.04 \times 0.03$ \\
\hline Goodness of fit on $\mathrm{F}^{2}$ & 1.117 & 1.041 \\
\hline $\mathrm{R} 1, w R 2[\mathrm{I}>2 \sigma(\mathrm{I})]$ & $0.0161,0.0404$ & $0.0258,0.0630$ \\
\hline R1, wR2 (all data) & $0.0173,0.0410$ & $0.0300,0.0648$ \\
\hline
\end{tabular}

\section{Results and discussion}

\subsection{Synthesis and characterization}

The compounds $\mathrm{ZnLCl}_{2}, \mathrm{CdLCl}_{2}$ and $\mathrm{CdLBr}_{2}$ crystallized without any solvents and in good phase purity, as discussed in the section Powder XRD and IR. The crystal structure of the compound $\mathrm{ZnLBr}_{2}$ has been reported previously [18]. In our synthesis of $\mathrm{ZnLBr}_{2}$, two different crystals were found and were isolated from the same batch; these two types of crystals were impossible to obtain as separate batches. Very interestingly, it appeared that one type of crystals crystallized with an acetonitrile molecule, namely $\left[\mathrm{ZnLBr}_{2}\right]\left(\mathrm{CH}_{3} \mathrm{CN}\right)$, the other one without any solvent, namely $\mathrm{ZnLBr}_{2}$. The elemental analysis of the bulk sample of $\mathrm{ZnLBr}_{2}$ is not fully in agreement with the calculated values for the solvent-free complex. The slight deviation can be fitted with partial inclusion of acetonitrile, suggesting that $\left[\mathrm{ZnLBr}_{2}\right]\left(\mathrm{CH}_{3} \mathrm{CN}\right)$ is present for only about $15 \%$ molar fraction in the powdered sample. However, the amount of $\left[\mathrm{ZnLBr}_{2}\right]\left(\mathrm{CH}_{3} \mathrm{CN}\right)$ 
present in the crystalline material may have been higher, as the powder was vacuum dried before the elemental analysis was performed.

\subsection{Crystal structure descriptions}

$\mathrm{ZnLCl}_{2}(\mathbf{1}), \mathrm{ZnLBr}_{2}(\mathbf{2 + 3}), \mathrm{CdLCl}_{2}(\mathbf{4})$ and $\mathrm{CdLBr}_{2}(\mathbf{5})$ all appeared to have the same molecular structure, and some of them are even isostructural with the same space group (see Tables 1 and 2). For this paper only the structure of $\mathrm{ZnLCl}_{2}(\mathbf{1})$ at $173 \mathrm{~K}$ is discussed in detail, as an example (see Figure 1a); the low-T and room-T structures differ only marginally due to lattice contraction. The asymmetric unit contains only one molecule of $\mathrm{ZnLCl}_{2}$. The $\mathrm{Zn}(\mathrm{II})$ ion is five coordinated by two $\mathrm{N}$ atoms and one $\mathrm{S}$ atom from the ligand, and two $\mathrm{Cl}^{-}$anions, with $\mathrm{Zn}-\mathrm{N}$ distances of 2.135(1) and 2.119(2) $\AA$, a Zn-S distance of 2.698(1) $\AA$, and Zn-Cl distances of 2.220(1) and 2.250(1) A. The ligand is bound in a meridional fashion and the halide ions occupy the remaining equatorial and the apical position of a square pyramid. The found bond lengths and angles can be considered as normal [18, 26, 27]. The coordination sphere of $\mathrm{Zn}(\mathrm{II})$ is best described as slightly distorted from square pyramidal towards trigonal bipyramidal, with $\tau$ (tau) values [28] varying from $0.13-0.26$ (see Table 3). One $\mathrm{Cl}^{-}$anion is relatively close to a hydrogen from a $\mathrm{C}$ atom of a neighboring molecule, i.e. $\mathrm{C}(7)-\mathrm{H}(7 \mathrm{~A})-\mathrm{Cl}(2)$, which has a contact distance $\mathrm{C}(7)-\mathrm{Cl}(2)$ of $3.542(2) \AA$ with a $\mathrm{C}(7)-\mathrm{H}(7 \mathrm{~A})-\mathrm{Cl}(2)$ angle of $159^{\circ}(1)$. The structure is further stabilized by intermolecular $\pi-\pi$ stacking interactions. The distance between adjacent aromatic rings are 3.8209(15) $\AA$ and 3.8166(13) $\AA$ (see Figure 1b).

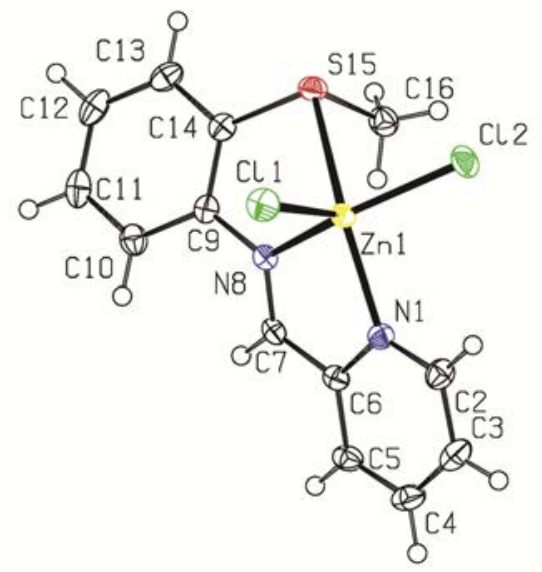

Figure 1a. The molecular structure (asymmetric unit of the crystal structure) and used atomic labelling of $\mathrm{ZnLCl}_{2}(\mathbf{1})$ at $173 \mathrm{~K}$. Ellipsoids are plotted at $50 \%$ probability. 


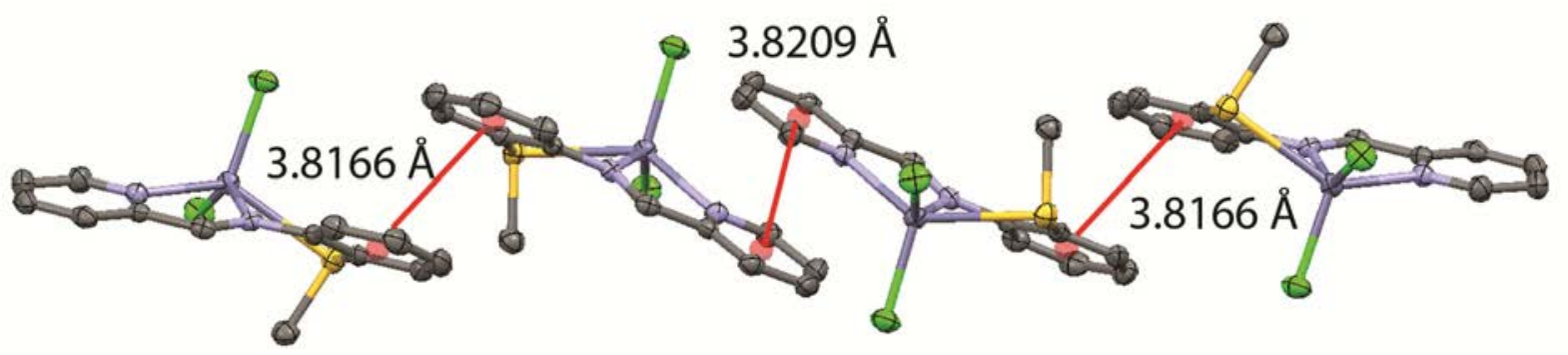

Figure 1b: An impression of the $\pi$-stacking interactions in $\mathrm{ZnLCl}_{2}(\mathbf{1})$. Distances given are between ring centers.

The asymmetric unit of $\left[\mathrm{ZnLBr}_{2}\right]\left(\mathrm{CH}_{3} \mathrm{CN}\right)(2)$ contains one molecule of the complex and one lattice solvent molecule (Figure S1). The $\mathrm{Zn}(\mathrm{II})$ ion in this case is also five-coordinated by two $\mathrm{N}$ atoms and one $\mathrm{S}$ atom from the ligand and two $\mathrm{Br}^{-}$ions, in a geometry that is very similar to that of the unsolvated molecule. The five-coordinate geometry is defined by a $\tau$ value [28] of 0.26 . The $\pi-\pi$ stacking interactions between adjacent aromatic rings have a centroid to centroid distance of 3.8595(10) $\AA$ (see Figure S2). No significant hydrogen bonds can be found in the structure. The acetonitrile molecule just fills void space in the lattice.

In $\mathrm{CdLCl}_{2}$ (4) and $\mathrm{CdLBr}_{2}(\mathbf{5})$ the distortion from square pyramidal towards trigonal bipyramidal is larger than that in the case of the $\mathrm{Zn}$ (II) complexes, as seen from the $\tau$ values, which are 0.36 and 0.37 , respectively. These changes are ascribed to the larger ionic radius of Cd(II). Relevant bond lengths, angles and $\tau$ values are also given in Table 3 . In all structures the methyl substituent at sulfur points in opposite direction of the apical halide. 
Table 3. Selected bond lengths $(\AA)$ and bond angles $\left(^{\circ}\right)$ of $\mathrm{ZnLCl}_{2}(\mathbf{1}),\left[\mathrm{ZnLBr}_{2}\right]\left(\mathrm{CH}_{3} \mathrm{CN}\right)(\mathbf{2}), \mathrm{ZnLBr}_{2}(\mathbf{3})$,

$\mathrm{CdLCl}_{2}(\mathbf{4})$ and $\mathrm{CdLBr}_{2}(\mathbf{5})$.

\begin{tabular}{|c|c|c|c|c|c|c|c|}
\hline $\begin{array}{l}\text { Distances } \\
\text { and angles }\end{array}$ & $\begin{array}{l}\text { 1: Low T } \\
\mathrm{ZnLCl}_{2}\end{array}$ & $\begin{array}{c}\text { 1: Room T } \\
\mathrm{ZnLCl}_{2}\end{array}$ & $\begin{array}{c}\text { 2: }\left[\mathrm{ZnLBr}_{2}\right]- \\
\left(\mathrm{CH}_{3} \mathrm{CN}\right)\end{array}$ & $\begin{array}{l}\text { 3: Low TR } \\
\mathrm{ZnLBr}_{2}\end{array}$ & $\begin{array}{l}\text { Lit: Room T } \\
\mathrm{ZnLBr}_{2}\end{array}$ & 4: $\mathrm{CdLCl}_{2}$ & 5: $\mathrm{CdLBr}_{2}$ \\
\hline M-N1 & $2.1191(14)$ & $2.1330(16)$ & $2.132(2)$ & $2.149(2)$ & 2.1496 & $2.355(1)$ & $2.351(2)$ \\
\hline M-N8 & $2.1354(14)$ & $2.1389(16)$ & $2.143(2)$ & 2.143(2) & 2.1215 & $2.345(1)$ & $2.3431(19)$ \\
\hline M-S15 & $2.6975(6)$ & $2.7406(6)$ & $2.639(1)$ & $2.6318(5)$ & 2.6444 & $2.7355(3)$ & $2.7269(7)$ \\
\hline $\mathrm{M}-\mathrm{C} 11 / \mathrm{Br} 1$ & $2.2196(7)$ & $2.2324(8)$ & $2.3745(3)$ & $2.3759(3)$ & 2.3669 & $2.4509(4)$ & $2.5686(3)$ \\
\hline $\mathrm{M}-\mathrm{C} 12 / \mathrm{Br} 2$ & $2.2504(7)$ & $2.2550(6)$ & $2.4233(3)$ & $2.4157(3)$ & 2.3990 & $2.4611(4)$ & $2.5829(3)$ \\
\hline $\mathrm{Cl} 1 / \mathrm{Br} 1-\mathrm{M}-\mathrm{Cl} 2 / \mathrm{Br} 2$ & $112.29(2)$ & 113.01(3) & $114.98(1)$ & $116.49(1)$ & 117.41 & $106.03(1)$ & $107.53(1)$ \\
\hline Cl1/Br1-M-S15 & $107.29(2)$ & $107.37(2)$ & $97.51(1)$ & $97.75(1)$ & 95.77 & $104.27(1)$ & $102.04(2)$ \\
\hline Cl1/Br1-M-N1 & $111.58(5)$ & $111.75(5)$ & $106.54(4)$ & $107.80(4)$ & 108.40 & $98.01(3)$ & $98.36(5)$ \\
\hline Cl1/Br1-M-N8 & $103.60(5)$ & $103.46(5)$ & $111.18(4)$ & $110.15(4)$ & 108.40 & $153.54(1)$ & $152.63(5)$ \\
\hline $\mathrm{Cl} 2 / \mathrm{Br} 2-\mathrm{M}-\mathrm{S} 15$ & $87.49(2)$ & $87.33(2)$ & $92.18(2)$ & $91.87(1)$ & 91.23 & $100.23(1)$ & $100.02(1)$ \\
\hline $\mathrm{Cl} 2 / \mathrm{Br} 2-\mathrm{M}-\mathrm{N} 1$ & $97.51(5)$ & $97.45(5)$ & $94.79(4)$ & $95.46(4)$ & 95.54 & $113.83(3)$ & $115.80(6)$ \\
\hline $\mathrm{Cl} 2 / \mathrm{Br} 2-\mathrm{M}-\mathrm{N} 8$ & $143.02(5)$ & $142.32(5)$ & $133.50(4)$ & $132.76(4)$ & 132.62 & $100.43(3)$ & $99.74(5)$ \\
\hline S15-M-N1 & $135.19(4)$ & $134.71(5)$ & $149.16(4)$ & $148.80(4)$ & 148.12 & $131.86(3)$ & $130.63(6)$ \\
\hline S15-M-N8 & $73.29(4)$ & 72.64(4) & $76.42(4)$ & 76.09(4) & 76.19 & $70.17(3)$ & $70.33(6)$ \\
\hline N1-M-N8 & $76.64(5)$ & $76.83(6)$ & $77.04(6)$ & $76.72(6)$ & 76.36 & $71.00(4)$ & $71.02(7)$ \\
\hline$\tau$ value $[28]$ & 0.131 & 0.127 & 0.26 & 0.25 & 0.26 & 0.36 & 0.37 \\
\hline
\end{tabular}




\subsection{Powder XRD and IR spectroscopy}

The crystallographic phase purity of all compounds has been checked by powder XRD and IR spectra. The $\mathrm{ZnLCl}_{2}(\mathbf{1}), \mathrm{CdLCl}_{2}(\mathbf{4})$ and $\mathrm{CdLBr}_{2}(\mathbf{5})$ samples show high purity and the experimental Powder XRD patterns are highly similar to the simulated X-ray diffraction patterns calculated from the single-crystal structures (Figure 2a, c, d). In agreement with the observation that the compound $\mathrm{ZnLBr}_{2}(\mathbf{2 + 3})$ contains two types of crystals, the experimental pattern contains all the main peaks from the two simulated patterns (Figure 2b). The IR spectra of all compounds are highly similar, which further supports that all the compounds are isostructural and that $\mathrm{ZnLBr}_{2}(\mathbf{3})$ is the main form present in the $\mathrm{ZnLBr}_{2}(\mathbf{2}+\mathbf{3})$ bulk sample (Figure S3).
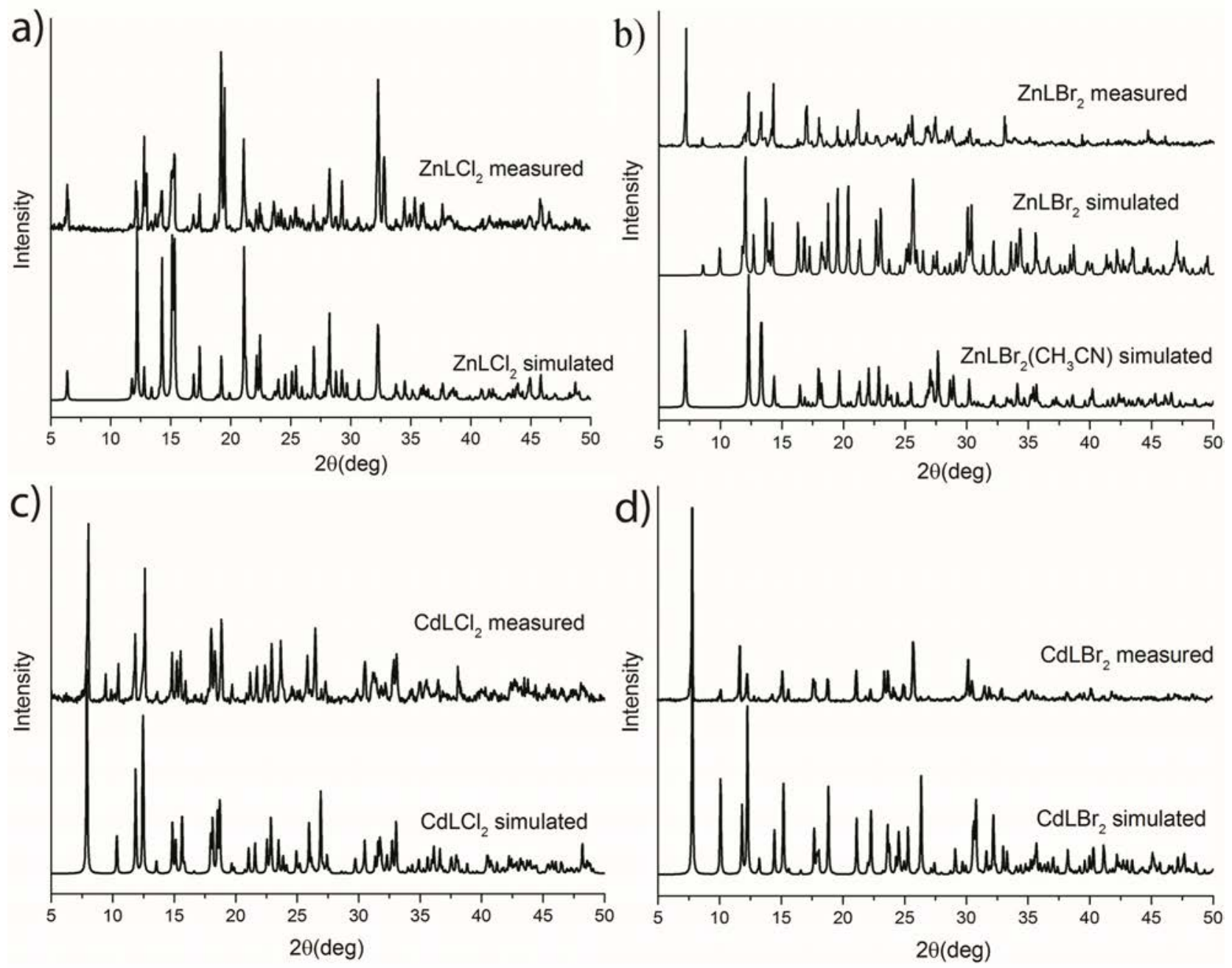

Figure 2. Experimental powder XRD patterns and simulated patterns from single-crystal structures. a) $\mathrm{ZnLCl}_{2}$ (1). b) $\mathrm{ZnLBr}_{2}$ (2+3). c) $\mathrm{CdLCl}_{2}$ (4). d) $\mathrm{CdLBr}_{2}$ (5). 


\subsection{Photophysical properties.}

The solid-state absorption spectra of the ligand and four complexes are shown in Figure S4. The ligand exhibits a strong broad absorption band from $250 \mathrm{~nm}$ to $450 \mathrm{~nm}$. The $\mathrm{ZnLCl}_{2}$ (1), $\mathrm{ZnLBr}_{2}(\mathbf{2 + 3})$ and $\mathrm{CdLCl}_{2}(\mathbf{4})$ absorption bands are slightly narrower than that of the ligand in the blue region, while the absorption spectrum of $\mathrm{CdLBr}_{2}(\mathbf{5})$ is similar to that of the ligand.

Room temperature excitation and emission spectra of $\mathrm{ZnLCl}_{2}(\mathbf{1}), \mathrm{ZnLBr}_{2}(\mathbf{2}+\mathbf{3}), \mathrm{CdLCl}_{2}$ (4) and $\mathrm{CdLBr}_{2}(\mathbf{5})$ were recorded in the solid state, and are depicted in Figure 3. The compounds $\mathrm{ZnLCl}_{2}(\mathbf{1})$ and $\mathrm{CdLC}_{2}(\mathbf{4})$ show a relatively intense yellow color emission, while $\mathrm{ZnLBr}_{2}(\mathbf{2 + 3})$, $\mathrm{CdLBr}_{2}(5)$ exhibit a medium intense yellow color emission upon irradiation of $400 \mathrm{~nm}$. The emission spectra of all four compounds contain only one peak with a maximum at around $540 \mathrm{~nm}$ (535 $\mathrm{nm}$ for the chloride compounds, $545 \mathrm{~nm}$ for the bromide compounds), which is assigned to the ligand $\pi-\pi^{*}$ transition [29-34]. For $\mathrm{ZnLCl}_{2}(\mathbf{1}), \mathrm{CdLCl}_{2}(\mathbf{4})$ and $\mathrm{CdLBr}_{2}(\mathbf{5})$; although the excitation spectra contain two peaks, varying the excitation wavelength did not make any influence of the shape and position of emission spectra. The room temperature quantum yields of $\mathrm{ZnLCl}_{2}(\mathbf{1})$ and $\mathrm{CdLC}_{2}(\mathbf{4})$ are $8 \%$ and $22 \%$, respectively. The quantum yield of $\mathrm{ZnLBr}_{2}(\mathbf{2}+\mathbf{3})$ and $\mathrm{CdLBr}_{2}(5)$ cannot be determined by our setup and is estimated to be at most $5 \%$.
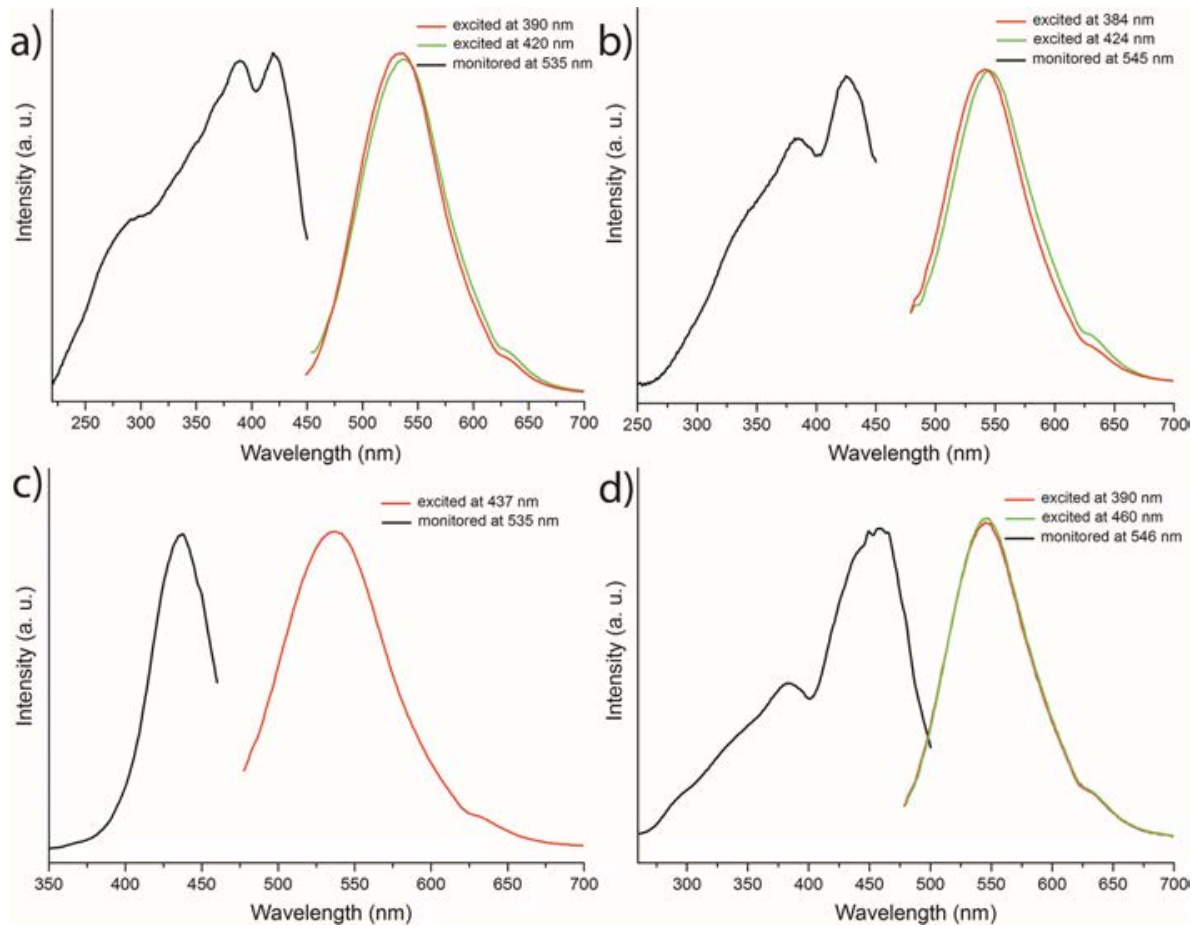

Figure 3. Room temperature excitation (black) and emission (red and green) spectra of a) $\mathrm{ZnLCl}_{2}$ (1); b) $\mathrm{ZnLBr}_{2}(\mathbf{2 + 3})$; c) $\mathrm{CdLCl}_{2}$ (4); d) $\mathrm{CdLBr}_{2}(\mathbf{5})$. 
The emission spectra of all four compounds have also been recorded at $77 \mathrm{~K}$ (see Figure S5). The emission color changes at $290 \mathrm{~K}$ and $77 \mathrm{~K}$ have been calculated and are presented in the so-called CIE (Commission International d'Elairage) chromaticity diagram (see Figure S6). The CIE coordinates are listed in Table S1; although the coordinates at different temperatures are significantly different, the color of emission remains largely the same. The emission spectra of all samples at $77 \mathrm{~K}$ are almost identical to their room temperature emission spectra. Interestingly, only the emission of the compound $\mathrm{CdLBr}_{2}$ seems to shift to a slightly more red color at lower temperatures.

\section{Concluding Remarks}

In summary, a series of $\mathrm{Zn}(\mathrm{II})$ and $\mathrm{Cd}(\mathrm{II})$ halide complexes, all containing the 2-(methylsulfanyl)-N-(pyridin-2-ylmethylidene)aniline ligand (L), has been successfully synthesized and characterized. The compounds $\mathrm{ZnLCl}_{2}(\mathbf{1}), \mathrm{ZnLBr}_{2}(\mathbf{2}+\mathbf{3}), \mathrm{CdLCl}_{2}$ (4) and $\mathrm{CdLBr}_{2}(\mathbf{5})$ have the same molecular structure based on IR and X-ray diffraction data. For all compounds the structures were solved by single-crystal X-ray diffraction. The compound $\mathrm{ZnLBr}_{2}$ was obtained as a mixture of two types of crystals, the pure $\mathrm{ZnLBr}_{2}(3)$ and the acetonitrile solvate $\left[\mathrm{ZnLBr}_{2}\right]\left(\mathrm{CH}_{3} \mathrm{CN}\right)(2)$; the unsolvated compound $\mathrm{ZnLBr}_{2}(3)$ appears to be the main component. All five compounds show a bright yellow luminescence emission. Temperature changes have negligible influence on the emission spectra.

\section{Appendix A. Supplementary data}

CCDC 1445927, 1446902, 1443691, 1446921, 1443712, and 1445920 contain the supplementary crystallographic data for $\mathrm{ZnLCl}_{2}(\mathbf{1}, 173 \mathrm{~K}), \mathrm{ZnLCl}_{2}(\mathbf{1}, 293 \mathrm{~K}),\left[\mathrm{ZnLBr}_{2}\right]\left(\mathrm{CH}_{3} \mathrm{CN}\right)(\mathbf{2}), \mathrm{ZnLBr}_{2}$ (3), $\mathrm{CdLCl}_{2}(4)$ and $\mathrm{CdLBr}_{2}(5)$, respectively. These data can be obtained free of charge via http://www.ccdc.cam.ac.uk/conts/retrieving.html, or from the Cambridge Crystallographic Data Centre, 12 Union Road, Cambridge CB2 1EZ, UK; fax: (+44) 1223-336-033; or e-mail: deposit@ccdc.cam.ac.uk.

Spectroscopic details in the supplementary data include: Packing and stacking diagrams for compounds $\mathbf{1}$ and $\mathbf{2}$. Infrared spectra and diffuse reflectance spectra of all new compounds. Also the CIE (Commission International d'Elairage) chromaticity diagrams are presented, in graphics and tabular form. 


\section{Acknowledgements:}

X. Liu gratefully acknowledges a grant from the Chinese Scholarship Council (no. 201206250014). Andrej Pevec thanks the Slovenian Research Agency for support (grant P10175). The Advanced Light Source is supported by the Director, Office of Science, Office of Basic Energy Sciences, of the U.S. Department of Energy under Contract No. DE-AC02$05 \mathrm{CH} 11231$.

\section{References}

[1] P. Pust, V. Weiler, C. Hecht, A. Tücks, A.S. Wochnik, A.K. Henß, D. Wiechert, C. Scheu, P.J. Schmidt, W. Schnick, Nat Mater, 13 (2014) 891-896.

[2] C.F. Zhu, S. Chaussedent, S.J. Liu, Y.F. Zhang, A. Monteil, N. Gaumer, Y.Z. Yue, J. Alloy. Compd., 555 (2013) 232-236.

[3] X. Liu, S. Akerboom, S.H.C. Askes, I. Mutikainen, E. Bouwman, Inorg. Chem. Commun., 61 (2015) 60-63.

[4] H. Kim, G.R. You, G.J. Park, J.Y. Choi, I. Noh, Y. Kim, S.J. Kim, C. Kim, R.G. Harrison, Dyes and Pigments, 113 (2015) 723-729.

[5] X.H. Qian, Z.C. Xu, Chem. Soc. Rev., 44 (2015) 4487-4493.

[6] X. Liu, S. Akerboom, M.d. Jong, I. Mutikainen, S. Tanase, A. Meijerink, E. Bouwman, Inorg. Chem., 54 (2015) 11323-11329.

[7] M. de Torres, S. Semin, I. Razdolski, J.L. Xu, J.A.A.W. Elemans, T. Rasing, A.E. Rowan, R.J.M. Nolte, Chem. Commun., 51 (2015) 2855-2858.

[8] R. Ghosh, S.H. Rahaman, C.N. Lin, T.H. Lu, B.K. Ghosh, Polyhedron, 25 (2006) 3104-3112.

[9] P. Suvanvapee, J. Boonmak, S. Youngme, Polyhedron, 102 (2015) 693-698.

[10] A.B. Pradhan, S.K. Mandal, S. Banerjee, A. Mukherjee, S. Das, A.R. Khuda Bukhsh, A. Saha, Polyhedron, 94 (2015) 75-82.

[11] M. Shyamal, A. Panja, A. Saha, Polyhedron, 69 (2014) 141-148.

[12] K.C. Gupta, A.K. Sutar, Coord. Chem. Rev., 252 (2008) 1420-1450.

[13] N.K. Al Rasbi, J. Husband, J. Photochem. Photobiol., 314 (2016) 96-103.

[14] N. Raman, A. Kulandaisamy, C. Thangaraja, K. Jeyasubramanian, Transit. Metal Chem., 28 (2003) 29-36.

[15] Z.L. Liu, J. Zhang, T.F. Li, Z.N. Yu, S.X. Zhang, J. Fluor. Chem., 147 (2013) 36-39.

[16] Z. Zhang, W.X. Feng, P.Y. Su, X.Q. Lü, J.R. Song, D.D. Fan, W.K. Wong, R.A. Jones, C.Y. Su, Inorg. Chem., 53 (2014) 5950-5960.

[17] M. Maiti, D. Sadhukhan, S. Thakurta, S. Roy, G. Pilet, R.J. Butcher, A. Nonat, L.J. Charbonnière, S. Mitra, Inorg. Chem., 51 (2012) 12176-12187.

[18] A. Mangia, M. Nardelli, C. Palmieri, G. Pelizzi, J. Cryst. Mol. Struct., 2 (1972) 99-106.

[19] J.C.de Mello, H.F. Wittmann, R. Friend, Adv.Mater., 9 (1997) 230-232

[20] J.S. Costa, A.G. Castro, R. Pievo, O. Roubeau, B. Modec, B. Kozlevcar, S.J. Teat, P. Gamez, J. Reedijk, CrystEngComm, 12 (2010) 3057-3064.

[21] A. Altomare, G. Cascarano, C. Giacovazzo, A. Guagliardi, J. Appl. Crystallogr., 27 (1994) 1045-1050. 
[22] G.M. Sheldrick, Acta Crystallogr. Sect. A, 64 (2008) 112-122.

[23] T. Kottke, D. Stalke, J. Appl. Crystallogr., 26 (1993) 615-619.

[24] Bruker, APEX2, SAINT and SADABS, 2007 and 2009. , in, Bruker AXS Inc., Madison, Wisconsin, USA, 2009.

[25] G.M. Sheldrick, Acta Crystallogr. Sect. C Struct. Chem 71 (2015) 3-8.

[26] H.L. Gao, S.X. Jiang, Y.M. Hu, F.F. Li, Q.Q. Zhang, X.Y. Shi, J.Z. Cui, Inorg. Chem. Commun., 44 (2014) 58-62.

[27] C. Bolm, K. Weickhardt, M. Zehnder, T. Ranff, Chem. Ber., 124 (1991) 1173-1180.

[28] A.W. Addison, T.N. Rao, J. Reedijk, J. van Rijn, G.C. Verschoor, J. Chem. Soc., Dalton Trans., (1984) 1349-1356.

[29] B. Dutta, P. Bag, U. Flörke, K. Nag, Inorg. Chem., 44 (2005) 147-157.

[30] S. Banthia, A. Samanta, J. Phys. Chem. B, 110 (2006) 6437-6440.

[31] W. Chen, Q. Peng, Y.D. Li, Cryst. Growth Des., 8 (2008) 564-567.

[32] Z. Li, A. Dellali, J. Malik, M. Motevalli, R.M. Nix, T. Olukoya, Y. Peng, H.Q. Ye, W.P. Gillin, I. Hernández, P.B. Wyatt, Inorg. Chem., 52 (2013) 1379-1387.

[33] S. Majumder, L. Mandal, S. Mohanta, Inorg. Chem., 51 (2012) 8739-8749.

[34] P. Yang, X.X. Wu, J.Z. Huo, B. Ding, Y. Wang, X.G. Wang, CrystEngComm, 15 (2013) 8097-8109. 


\section{Graphical abstract}

Five-coordinated zinc and cadmium complexes with the ligand 2-(methylsulfanyl)-N(pyridin-2-yl-methylidene)aniline have been synthesized, and characterized by NMR, IR, elemental analysis, X-ray crystallography, Powder XRD and luminescence. 